\title{
Childhood asthma in low income countries: an invisible killer?
}

\section{* Marianne Stubbe Østergaarda, Rebecca Nantanda', James K Tumwine ${ }^{b}$, Rune Aabenhus ${ }^{a}$}

a Department of General Practice and Research Unit of General Practice, University of Copenhagen, Copenhagen, Denmark

${ }^{b}$ Department of Paediatrics and Child Health, Makerere University College of Health Sciences, Kampala, Uganda

Originally received 6th December 2011; resubmitted 14th February 2012; revised 5th M arch 2012; accepted 13th March 2012; online 23rd M ay 2012

\begin{abstract}
Bacterial pneumonia has hitherto been considered the key cause of the high respiratory morbidity and mortality in children under five years of age (under-5s) in low-income countries, while asthma has not been stated as a significant reason. This paper explores the definitions and concepts of pneumonia and asthma/wheezing/bronchiolitis and examines whether asthma in under-5s may be confused with pneumonia. Over-diagnosing of bacterial pneumonia can be suspected from the limited association between clinical pneumonia and confirmatory test results such as chest x-ray and microbiological findings and poor treatment results using antibiotics. Moreover, children diagnosed with recurrent pneumonia in infancy were often later diagnosed with asthma. Recent studies showed a 10-15\% prevalence of preschool asthma in low-income countries, although under-5s with long-term cough and difficulty breathing remain undiagnosed. New studies demonstrate that approximately $50 \%$ of acutely admitted under-5s diagnosed with pneumonia according to Integrated Management of Childhood IInesses could be re-diagnosed with asthma or wheezing when using re-defined diagnostic criteria and treatment. It is hypothesised that untreated asthma may contribute to respiratory mortality since respiratory syncytial virus (RSV) is an important cause of respiratory death in childhood, and asthma in under-5s is often exacerbated by viral infections, including RSV. Furthermore, acute respiratory treatment failures were predominantly seen in under-5s without fever, which suggests the diagnosis of asthma/wheezing rather than bacterial pneumonia. Ultimately, underlying asthma may have contributed to malnutrition and fatal bacterial pneumonia. In conclusion, preschool asthma in low-income countries may be significantly under-diagnosed and misdiagnosed as pneumonia, and may be the cause of much morbidity and mortality.

(C) 2012 Primary Care Respiratory Society UK. All rights reserved.

MS Østergaard et al. Prim Care Respir J 2012; 21(2): 214-219

http://dx.doi.org/10.4104/pcrj.2012.00038
\end{abstract}

Keywords acute respiratory infections, pneumonia, asthma, under-diagnosis, under-5s, mortality

\section{Introduction}

Acute respiratory infections (ARI) are the major cause of morbidity and mortality in children under five years of age (under-5s) in low-income countries ${ }^{1-7}$ and account for more than $20 \%$ of estimated child deaths annually. ${ }^{1-6}$ ARI and pneumonia are often used synonymously although ARI is an umbrella term for several respiratory diseases. ${ }^{8,9}$ The case fatality rate from pneumonia in hospitalised under-5s remains at $11-15 \%, 4,7,10-12$ but it can be as high as $30 \% .^{13}$ Mortality in under-5s is particularly high in Sub-Saharan Africa. ${ }^{14,15}$

The global strategies to reduce mortality from pneumonia aim to improve correct diagnoses and case management using the World Health Organization (WHO) Integrated Management of Childhood IInesses (IMCI) guidelines ${ }^{14,16,17}$ that recommend the use of simple clinical signs and optimal antibiotic treatment.
Furthermore, preventive vaccination programmes, strengthening health systems, and improving nutrition are focal points. ${ }^{6}$

Despite much scientific effort since 1980, there has not been a significant reduction in respiratory mortality in under-5s. ${ }^{6}$ The reason for the continued high level of respiratory mortality has not been clearly established. ${ }^{12,18}$ Lack of diagnostic facilities and trained personnel in under-resourced health centres may contribute to missed diagnoses. ${ }^{19-22}$

Recent studies have brought into question whether strict implementation of the $\mathrm{IMCl}$ guidelines may result in an overdiagnosis of bacterial pneumonia and an over-prescription of antibiotics at the expense of an under-diagnosis of asthma or wheezing. ${ }^{23-27}$ A re-definition of the WHO IMCl algorithms for pneumonia to include fever along with cough and fast breathing for diagnosing pneumonia has been proposed. 22,28,29

\footnotetext{
* Corresponding author: Dr M arianne Stubbe Østergaard, Department of General Practice and Research Unit of General Practice, University of Copenhagen, Øster Farimagsgade 5, Copenhagen DK 1014K, Denmark. Tel: +45 26331111 E-mail: moster@sund.ku.dk
} 
This paper explores the definitions and concepts of pneumonia and asthma/wheezing/bronchiolitis and examines whether asthma in the under-5s may be being confused with bacterial pneumonia. It also debates whether the inappropriate management of asthma may be contributing to the current high level of respiratory morbidity and mortality in the under- $5 \mathrm{~s}$ in low-income countries.

\section{Concepts, definitions and overlap of clinical features}

Pneumonia is traditionally defined as an acute infection in the alveolar tissue caused by bacteria, virus, or other microorganisms, and a chest $\mathrm{x}$-ray is the gold standard in the diagnosis of bacterial pneumonia. According to the British Thoracic Society (BTS) pneumonia guidelines, ${ }^{30,31}$ bacterial pneumonia should be considered in children with persistent or repetitive fever of $>38.5^{\circ} \mathrm{C}$ together with chest recession and raised respiratory rate.

The $\mathrm{WHO} \mathrm{IMCl}$ strategy promotes a classification of pneumonia in children in resource-limited settings presenting with 'cough or difficult breathing', while fever was not included in the management guidelines of pneumonia aiming at a high sensitivity at the cost of specificity. The WHO recommends making the diagnosis of pneumonia based on clinical parameters. ${ }^{16}$ The clinical features of bacterial pneumonia and asthma in the under-5s, adapted from the $\mathrm{WHO} I \mathrm{IMCl}$ guidelines, ${ }^{16,17}$ illustrate an overlap in symptoms and signs (Table 1). However, asthma is only briefly described in the $I M C I$ guidelines, so the severity levels of asthma in Table 1 are adapted from the Global Initiative for Asthma (GINA) guidelines. ${ }^{32}$

Asthma is defined as an inflammatory disorder with hyperreactive airways resulting in 'chronic or recurrent wheeze, cough and/or breathing difficulties, particularly at night and early morning', ${ }^{32,33}$ and is potentially remittent. Major conceptual changes in childhood asthma have been instituted in the last decades with regard to definition, natural history, triggers, and treatment. Epidemiological studies have provided convincing evidence that the symptoms of asthma often start in early childhood. ${ }^{34}$ Acute asthma may be exacerbated by viral infections, ${ }^{32,35-37}$ often by respiratory syncytial virus (RSV) in children aged $<2$ years, ${ }^{32}$ probably in a bidirectional way since asthma seems to be associated with increased susceptibility to severe RSV disease. ${ }^{38}$ Open fire biomass cooking may be an important risk factor for preschool asthma symptoms ${ }^{39}$ and respiratory infections..$^{40}$

The terms 'asthma', 'wheezing disorder' and 'bronchiolitis' are often used in paralle|li ${ }^{41}$ and present with similar symptoms, ${ }^{34,41}$ triggers, ${ }^{34,42}$ and treatment (Table 2).

Wheezing disorder ${ }^{43}$ includes 'episodic viral wheeze' to describe children who wheeze intermittently ${ }^{43}$ and 'multipletrigger wheeze' for wheezing triggered by viruses and other

Table 1. Clinical features of bacterial pneumonia adapted from the World Health Organization's Integrated

Management of Childhood IIInesses (IMCI) guidelines and asthma adapted from Global Initiative for Asthma (GINA) guidelines

\begin{tabular}{lll} 
Clinical features & Bacterial pneumonia & Asthma \\
\hline Natural history & Acute onset, often only one episode & $\begin{array}{l}\text { Chronic or recurrent with acute exacerbations often } \\
\text { starting in infancy }\end{array}$ \\
\hline Triggers & Bacteria, virus & Virus (especially RSV, HRV) allergens \\
\hline Mild symptoms & Cough, difficult breathing & Cough, difficult breathing and/or wheezing \\
\hline Severe symptoms & $\begin{array}{l}\text { Cough and difficult breathing, fast breathing, } \\
\text { chest in-drawing }\end{array}$ & $\begin{array}{l}\text { Cough and difficult breathing, fast breathing, chest } \\
\text { in-drawing, +/- wheeze, prolonged expiration }\end{array}$ \\
\hline Very severe symptoms & $\begin{array}{l}\text { Cough and/or difficult breathing, fast breathing, } \\
\text { chest in-drawing, inability to feed, cyanosis, } \\
\text { lethargy }\end{array}$ & $\begin{array}{l}\text { Cough and/or difficult breathing, fast breathing, } \\
\text { chest in-drawing, inability to feed, cyanosis, lethargy, } \\
\text { wheeze loud or +/- absent }\end{array}$ \\
\hline
\end{tabular}

HRV=human rhinovirus, RSV=respiratory syncytial virus.

Table 2. Clinical features of asthma, wheezing disorder and bronchiolitis

\begin{tabular}{llll} 
& Asthma & Wheezing disorder & Bronchiolitis \\
\hline Natural history & $\begin{array}{l}\text { Recurrent or chronic with } \\
\text { acute exacerbations, often starting } \\
\text { in infancy }\end{array}$ & $\begin{array}{l}\text { Intermittent or chronic often } \\
\text { starting in infancy }\end{array}$ & $\begin{array}{l}\text { First manifestation of severe wheezing in } \\
\text { children aged }<12-24 \text { months }\end{array}$ \\
\hline $\begin{array}{l}\text { Symptoms as } \\
\text { described in IMCl }\end{array}$ & $\begin{array}{l}\text { Cough, difficult breathing and/or } \\
\text { wheezing, prolonged expiration, } \\
\text { chest in-drawing }\end{array}$ & Wheezing, prolonged expiration & $\begin{array}{l}\text { Cough, difficult breathing and/or wheezing, } \\
\text { prolonged expiration, chest in-drawing }\end{array}$ \\
\hline Triggers & Viruses (including RSV, HRV), allergens & Viruses (including RSV, HRV), allergens & Viruses including RSV, HRV \\
\hline Treatment proposal & Steroids and $\beta_{2}$-agonists & $\begin{array}{l}\text { Steroids and } \beta_{2} \text {-agonists and/or } \\
\text { montelukast }\end{array}$ & $\begin{array}{l}\text { Steroids, adrenaline, antibiotics, } \\
\beta_{2} \text {-agonists often used }\end{array}$ \\
\hline
\end{tabular}

HRV=human rhinovirus, IMCI=Integrated Management of Childhood IIInesses, RSV=respiratory syncytial virus. 
triggers. ${ }^{43}$ Recommended treatments are short-acting $\beta_{2}$ agonists, steroids, and/or montelukast..43

Bronchiolitis is traditionally described as the first manifestation of severe wheezing in infants. ${ }^{44,45}$ It remains a clinical diagnosis without a common international definition. ${ }^{41}$ Supportive treatment and antibiotics are recommended; ${ }^{17}$ however, adrenaline alone or in combination with prednisolone has been found to be effective, ${ }^{46}$ and various treatments such as short-acting $\beta_{2}$-agonists, prednisone, and antibiotics are used in practice. ${ }^{47}$

We have chosen to use the term 'asthma' in the under-5s because asthma is well described ${ }^{32}$ and because the term asthma implies well-established treatment, follow-ups, and prophylaxis at discharge. We acknowledge the risk of over-diagnosing asthma. However, as asthma is defined as a recurrent/chronic and potentially remittent disease, it implies regular diagnostic reevaluations. ${ }^{32}$

\section{Over-diagnosis of bacterial pneumonia}

Several studies have brought into question whether strict implementation of the $\mathrm{IMCl}$ guidelines may result in an overdiagnosis of bacterial pneumonia. ${ }^{23-25,48}$ Herewith several indices which highlight possible over-diagnosis of bacterial pneumonia are listed: In a study of 2,000 young children in six Pakistani hospitals who were suspected to have, and were treated for, non-severe bacterial pneumonia on the basis of fast breathing, fewer than $20 \%$ had alveolar consolidation on the chest $x$-ray. ${ }^{49}$ In microbiological studies of under-5s diagnosed with severe pneumonia, virus came out as the predominant pathological agent. In South Africa, pathogens were isolated in $65 \%$ of cases and viral pathogens predominated, with RSV being the most common; only $17.7 \%$ had bacteraemia and Streptococcus pneumoniae and Haemophilus influenzae were not isolated. ${ }^{13}$ In a sample of Kenyan infants and children admitted with severe pneumonia to a rural hospital, RSV was the predominant viral pathogen and was detected in almost half of the infants..$^{50}$

With regard to antibiotic treatment of pneumonia, the reduction in severe respiratory illness was minor despite frequent contacts with health facilities and early stage antibiotic treatment of children suspected with pneumonia in Uganda. ${ }^{51}$ Moreover, several comparative studies showed equivalent treatment results between different types, doses, and administration forms of antibiotics in children with IMCl-defined pneumonia. ${ }^{52-54}$ Treatment failures of serious pneumonia were primarily related to infants (3-11 months) with very fast breathing, chest indrawings and hypoxia ${ }^{10,11,53}$ and long-term cough, ${ }^{10}$ but were not associated with fever, ${ }^{10,11,54}$ raising questions concerning the diagnosis of bacterial pneumonia according to BTS guidelines. ${ }^{30,31}$

\section{Under-diagnosis of asthma}

Recent evidence has challenged the perception that asthma is a disease of low prevalence in young children in developing countries compared with industrialised countries. The ISAAC study demonstrated a high prevalence of asthma in schoolchildren in low-income countries; ${ }^{55}$ for example, in Mozambique the prevalence of current asthma was $13.3 \%$ in schoolchildren aged 6-7 years ${ }^{56}$ and the 1-year prevalence among children aged $5-6$ years in Bangladesh was $16.1 \% .{ }^{57}$ Of the few studies reported in under- $5 \mathrm{~s}$, the prevalence of asthma in 4-year-old children in Tanzania was found to be $14.0 \%$ and the prevalence of current wheezing during infancy was $13.8 \% .^{58}$ In Brazil the prevalence of wheeze in 6-59-month-old children was $12.5 \%$, of whom $93 \%$ were reported with a medical diagnosis of asthma. ${ }^{59}$

With regard to chronic respiratory problems in under-5s, cough and breathing difficulties were highly prevalent in Ugandan children aged $<2$ years exposed in interviews using 2week recall; of 3,249 children studied, 10\% reported cough, difficult or rapid breathing and/or fever. ${ }^{60}$ None of these children had been diagnosed with or treated for asthma or wheeze, although recurrent cough and difficult breathing are core symptoms of asthma. Similarly, ethnographic studies from several regions of Africa, Asia, and Latin America described longterm cough and breathing difficulties in under-5s interpreted as respiratory illness or infections. ${ }^{61,62}$ When the symptoms deteriorated and the mothers sought help, the antibiotics given were of limited efficacy. ${ }^{61,62}$ Also, infants and toddlers from indigenous populations in Australia, New Zealand, and Canada experienced frequent severe undiagnosed and untreated recurrent wheezing and chronic cough. ${ }^{63}$

Historically, there has been a diagnostic delay in young children with asthma. ${ }^{64-67}$ In South Africa, a delay in diagnosis of three years was found in half of the children who were later diagnosed with asthma. ${ }^{68}$ The reasons for delayed diagnoses included doctors trivialising the respiratory consultations and overemphasising infectious diagnoses and clinging to outdated asthma concepts. ${ }^{67}$ In addition, the diagnostic key symptom such as stetoscopic wheeze may not be present, and audible wheeze is only present in around $30 \%$ of children with auscultatory wheeze. ${ }^{48,69}$

\section{Asthma misdiagnosed as pneumonia}

A key question is whether the $\mathrm{WHO} I \mathrm{MCl}$ guidelines may result in over-diagnosis of pneumonia and subsequently overprescription of antibiotics at the cost of under-diagnosis and under-treatment of asthma or wheezing. ${ }^{23-27}$ In Uganda, pneumonia accounted for up to $30 \%$ of admissions ${ }^{11}$ and only $0.1 \%$ of the acutely admitted under- $5 \mathrm{~s}$ were diagnosed with asthma. ${ }^{70}$

Four clinical studies have indicated an over-diagnosis of pneumonia at the expense of under-diagnosis of asthma or wheezing in approximately $50 \%$ of cases by using a change in diagnostic and prescription policy when under-5s were admitted and diagnosed with pneumonia, ${ }^{29,48,54,69}$ as shown in Table 3 . Sachdev et al. stated that, on the basis of re-defined $\mathrm{IMCl}$ algorithms and subsequently rational use of antibiotics and 
Table 3. Over-diagnosis of pneumonia at the cost of under-diagnosis of asthma/wheeze in children admitted with acute respiratory infection and diagnosed with pneumonia

\begin{tabular}{|c|c|c|c|c|}
\hline & \multirow[t]{2}{*}{ Age (months) } & \multirow{2}{*}{$\begin{array}{l}\text { IMCl-defined pneumonia } \\
\text { Number }\end{array}$} & \multicolumn{2}{|c|}{$\begin{array}{l}\text { Diagnosis when using redefined } \mathrm{IMCl} \text { criteria } \\
\text { and/or responding to bronchodilators }\end{array}$} \\
\hline & & & Pneumonia & Asthma and/or wheezing \\
\hline Sachdev $(2001)^{69}$ & $6-59$ & 200 & $10 \%$ & $46-54 \%$ \\
\hline Hazir $(2004)^{48}$ & $1-59$ & 1622 & & $49 \%$ \\
\hline Addo-Yobo $(2004)^{54}$ & $3-59$ & 1702 & & $50 \%$ \\
\hline Cardoso $(2011)^{29}$ & $2-59$ & 410 & $18 \%$ & $73 \%$ \\
\hline
\end{tabular}

bronchodilators, acute asthma was the predominant condition. ${ }^{69}$

Epidemiological studies suggest that children diagnosed with recurrent pneumonia in infancy are often later diagnosed with asthma. ${ }^{25,57,71,72}$ Heffelfinger et al. suggested that children diagnosed with recurrent pneumonia according to IMCI-criteria in Haiti, compared with children never diagnosed with pneumonia, were more likely to get an asthma diagnosis later, and asthma should be considered as an alternatiove diagnosis to recurrent pneumonia. ${ }^{25}$

\section{Asthma in the under-5s: an invisible killer?}

Ultimately, it can be hypothesised that untreated asthma contributes to respiratory mortality for the following reasons. Acute respiratory infection treatment failures were predominantly seen in cases with cough of $>14$ days before admission or prior admissions for acute respiratory infection ${ }^{10}$ or cases with very fast breathing, hypoxia, but without fever, ${ }^{11,54}$ which are typical features of severe asthma rather than bacterial pneumonia which is characterised by fever $>38.5^{\circ} \mathrm{C} .{ }^{30,31}$ Secondly, mortality data from low-income countries showed that RSV is an important cause of respiratory death in childhood. ${ }^{73,74}$ Since asthma in young children is often exacerbated by viral infections including RSV . $3,35,37,75$ and since viral infections are usually selflimiting diseases, ${ }^{75}$ it is likely that RSV infections develop severely in children with underlying hyper-reactive airways as in asthma, and that untreated asthma may develop into fatal asthma. ${ }^{75}$

Moreover, long-term cough and untreated asthma may reduce the child's ability to breast feed ${ }^{76}$ which relates to lower weight and height ${ }^{77,78}$ and may lead to malnutrition. ${ }^{79}$ Malnutrition and acute respiratory infection/pneumonia are interrelated health problems affecting children in developing countries, $^{80,81}$ and malnutrition is often an underlying cause of recurrent and fatal pneumonia. ${ }^{10,11}$ Underlying asthma causing malnutrition may therefore contribute to fatal pneumonia/ respiratory infection.

Short courses of high-dose inhaled corticosteroids (ICS) for wheeze and acute asthma in infants and toddlers ${ }^{82}$ have been demonstrated to be effective ${ }^{83,84}$ and safe. ${ }^{83}$ It is well established that no treatment or under-treatment with ICS is a risk factor for fatal asthma, ${ }^{85}$ and that asthma mortality in children in highincome countries declined significantly with adequate acute treatment and prophylaxis with ICS. ${ }^{32}$ However, ICS are seldom used to treat under-5s in Africa due to former ignorance of asthma in under- $5 \mathrm{~s}$ and because of non-availability and unaffordability of ICS ${ }^{86}$

\section{Conclusions}

This paper indicates that an overlap in clinical features between bacterial pneumonia and asthma in under-5s using $\mathrm{IMCl}$ guidelines, and variability in the terms used for severe cough and wheezing, and a former lack of awareness of asthma in the under-5s, may be contributing to a significant under-diagnosis of asthma which, in turn, may have caused much respiratory morbidity, recurrent admissions, and even mortality. This hypothesis may be directly relevant to the WHO Millennium Development Goal 4 which aims to reduce childhood mortality by two-thirds between 1990 and 2015.87,88 Moreover, misdiagnosis may cause impoverishment of low-income families spending large sums of money on often inappropriate antibiotics.

The proposed re-definition of the $\mathrm{IMCl}$ algorithms for pneumonia to include high fever along with cough and fast breathing for diagnosing pneumonia ${ }^{22,23,27-29}$ is supported. One direction for future research is the development of simple valid algorithms based on detailed clinical history including wheeze to improve differentiation between pneumonia and asthma, in line with former proposals. Another direction would be the study of affordable, simple, and cost-effective management strategies for asthma in under-5s in low-income countries.

\section{Handling editor Mike Thomas}

Acknowledgements We greatly appreciate the thoughtful comments of Hilary Pinnock, Allergy and Respiratory Research Group, Centre for Population Health Sciences, University of Edinburgh, UK; Rupert Jones, Respiratory Research Unit, Plymouth, UK; and Freddy Karup Pedersen and Anja Poulsen, both from the Paediatric Department, Rigshospitalet, Copenhagen, Denmark.

Conflicts of interest The authors declare that they have no conflicts of interest in relation to this article.

Contributorship MSØ designed and wrote the manuscript. RA, RN and JKT co-authored the manuscript and revised and approved the final version.

Funding The Danish Foreign Offices Development and Research Fund

\section{References}

1. Denny FW, Loda FA. Acute respiratory infections are the leading cause of death in children in developing countries. Am J Trop Med Hyg 1986;35(1):1-2. 
2. Kabra SK, Lodha R, Pandey RM. Antibiotics for community acquired pneumonia in children. Cochrane Database Syst Rev 2006;(3):CD004874.

3. Bryce J, Boschi-Pinto C, Shibuya K, Black RE. WHO estimates of the causes of death in children. Lancet 2005;365(9465):1147-52. http://dx.doi.org/10.1016/S0140-6736(05)71877-8

4. Rudan I, Tomaskovic L, Boschi-Pinto C, Campbell H. Global estimate of the incidence of clinical pneumonia among children under five years of age. Bull World Health Organ 2004;82(12):895-903.

5. Wardlaw T, Salama P, Johansson EW, Mason E. Pneumonia: the leading killer of children. Lancet 2006;368(9541):1048-50. http://dx.doi.org/10.1016/S0140-6736(06)69334-3

6. Mulholland K. Childhood pneumonia mortality: a permanent global emergency. Lancet 2007;370(9583):285-9. http://dx.doi.org/10.1016/S0140-6736(07)61130-1

7. Bhutta ZA. Managing severe pneumonia in children in developing countries. BMJ 2008;336(7635):57-8. http://dx.doi.org/10.1136/bmj.39426.672118.80

8. Lanata CF, Rudan I, Boschi-Pinto $C$, et al. Methodological and quality issues in epidemiological studies of acute lower respiratory infections in children in developing countries. Int J Epidemiol 2004;33(6):1362-72. http://dx.doi.org/10.1093/ije/dyh229

9. Bellos A, Mulholland K, O'Brien KL, et al. The burden of acute respiratory infections in crisis-affected populations: a systematic review. Confl Health 2010;4(1):3. http://dx.doi.org/10.1186/1752-1505-4-3

10. Nathoo KJ, Nkrumah FK, Ndlovu D, Nhembe M, Pirie DJ, Kowo H. Acute lower respiratory tract infection in hospitalized children in Zimbabwe. Ann Trop Paediatr 1993;13(3):253-61.

11. Nantanda R, Hildenwall H, Peterson S, Kaddu-Mulindwa D, Kalyesubula I, Tumwine $\mathrm{K}$. Bacterial aetiology and outcome in children with severe pneumonia in Uganda. Ann Trop Paediatr 2008;28(4):253-60. http://dx.doi.org/10.1179/ 146532808X375404

12. Djelantik IG, Gessner BD, Sutanto A, et al. Case fatality proportions and predictive factors for mortality among children hospitalized with severe pneumonia in a rural developing country setting. J Trop Pediatr 2003;49(6):327-32. http://dx.doi.org/10.1093/tropej/49.6.327

13. Delport SD, Brisley T. Aetiology and outcome of severe community-acquired pneumonia in children admitted to a paediatric intensive care unit. S Afr Med J 2002;92(11):907-11.

14. United Nations Children's Fund (UNICEF)/World Health Organization (WHO). Pneumonia. The forgotten killer of children. 2006.

15. Rajaratnam JK, Marcus JR, Flaxman AD, et al. Neonatal, postneonatal, childhood, and under-5 mortality for 187 countries, 1970-2010: a systematic analysis of progress towards Millennium Development Goal 4. Lancet 2010;375(9730):19882008. http://dx.doi.org/10.1016/S0140-6736(10)60703-9

16. UNICEF/WHO. Integrated management of childhood illness. Chart booklet. UNICEF/WHO, 2008.

17. World Health Organization. Pocket book of hospital care for children. Guidelines for the management of common illnesses with limited resources. World Health Organization, 2005.

18. Scott JA, Brooks WA, Peiris JS, Holtzman D, Mulhollan EK. Pneumonia research to reduce childhood mortality in the developing world. J Clin Invest 2008;118(4):1291300. http://dx.doi.org/10.1172/JCl33947

19. Reyburn $\mathrm{H}, \mathrm{M}$ wakasungula $\mathrm{E}, \mathrm{Chonya} \mathrm{S}$, et al. Clinical assessment and treatment in paediatric wards in the north-east of the United Republic of Tanzania. Bull World Health Organ 2008;86(2):132-9. http://dx.doi.org/10.2471/BLT.07.041723

20. Kizza IB, Tugumisirize J, Tweheyo R, et al. Makerere University College of Health Sciences' role in addressing challenges in health service provision at Mulago National Referral Hospital. BMC International Health and Human Rights 2011;11(Suppl 1):S7. http://dx.doi.org/10.1186/1472-698X-11-S1-S7

21. Kissoon N. Out of Africa: a mother's journey. Pediatr Crit Care Med 2011;12(1):739. http://dx.doi.org/10.1097/PCC.0b013e3181ce74ef

22. Graham SM, English M, Hazir T, Enarson P, Duke T. Challenges to improving case management of childhood pneumonia at health facilities in resource-limited settings. Bull World Health Organ 2008;86(5):349-55 http://dx.doi.org/10.2471/ BLT.07.048512

23. Sachdev HP, Vasanthi B, Satyanarayana L, Puri RK. Simple predictors to differentiate acute asthma from ARI in children: implications for refining case management in the ARI control programme. Indian Pediatr 1994;31(10):1251-9.

24. Shah D, Sachdev HP. Evaluation of the WHO/UNICEF algorithm for integrated management of childhood illness between the age of two months to five years. Indian Pediatr 1999;36(8):767-77.

25. Heffelfinger JD, Davis TE, Gebrian B, Bordeau R, Schwartz B, Dowell SF. Evaluation of children with recurrent pneumonia diagnosed by World Health Organization criteria. Pediatr Infect Dis ] 2002;21(2):108-12. http://dx.doi.org/10.1097/00006454-200202000-00005

26. Hazir T, Qazi SA, Nisar YB, et al. Can WHO therapy failure criteria for non-severe pneumonia be improved in children aged 2-59 months? Int J Tuberc Lung Dis 2006;10(8):924-31.

27. Savitha MR, Khanagavi JB. Redefining the World Health Organization algorithm for diagnosis of pneumonia with simple additional markers. Indian J Pediatr 2008;75(6):561-5. http://dx.doi.org/10.1007/s12098-008-0108-4

28. Castro AV, Nascimento-Carvalho CM, Ney-Oliveria F, et al. Additional markers to refine the World Health Organization algorithm for diagnosis of pneumonia. Indian Pediatr 2005;42(8):773-81.

29. Cardoso MR, Nascimento-Carvalho CM, Ferrero F, Alves FM, Cousens SN. Adding fever to WHO criteria for diagnosing pneumonia enhances the ability to identify pneumonia cases among wheezing children. Arch Dis Child 2011;96(1):58-61. http://dx.doi.org/10.1136/adc.2010.189894

30. British Thoracic Society. Guidelines for the management of community acquired pneumonia in childhood. Thorax 2002;57(Suppl 1):i1-24.

31. Harris M, Clark J, Coote N, et al. British Thoracic Society guidelines for the management of community acquired pneumonia in children: update 2011. Thorax 2011;66(Suppl 2):ii1-23. http://dx.doi.org/10.1136/thoraxjnl-2011-200598

32. Global Initiative for Asthma (GINA). Global strategy for asthma management and prevention, 2009. http://www.ginasthma.org.

33. Warner JO, Gotz M, Landau LI, et al. Management of asthma: a consensus statement. Arch Dis Child 1989;64(7):1065-79. http://dx.doi.org/10.1136/ adc.64.7.1065

34. Martinez FD. Recognizing early asthma. Allergy 1999;54(Suppl 49):24-8. http://dx.doi.org/10.1111/j.1398-9995.1999.tb04384.x

35. Pattemore PK, Johnston SL, Bardin PG. Viruses as precipitants of asthma symptoms. I. Epidemiology. Clin Exp Allergy 1992;22(3):325-36. http://dx.doi.org/10.1111/ j.1365-2222.1992.tb03094.x

36. Mallia $P$, Johnston SL. How viral infections cause exacerbation of airway diseases Chest 2006;130(4):1203-10. http://dx.doi.org/10.1378/chest.130.4.1203

37. Martinez FD. The connection between early life wheezing and subsequent asthma: the viral march. Allergollmmunopathol (Madr) 2009;37(5):249-51. http://dx.doi.org/10.1016/j.aller.2009.06.008

38. Stensballe LG, Simonsen JB, Thomsen SF, et al. The causal direction in the association between respiratory syncytial virus hospitalization and asthma. J Allergy Clin Immunol 2009;123(1):131-7. http://dx.doi.org/10.1016/j.jaci.2008.10.042

39. Schei MA, Hessen JO, Smith KR, Bruce N, M cCracken J, Lopez V. Childhood asthma and indoor woodsmoke from cooking in Guatemala. J Exposure Anal Environ Epidemiol 2004;14(Suppl 1):S110-7. http://dx.doi.org/10.1038/sj.jea.7500365

40. Po JY, FitzGerald JM, Carlsten C. Respiratory disease associated with solid biomass fuel exposure in rural women and children: systematic review and meta-analysis. Thorax 2011;66(3):232-9. http://dx.doi.org/10.1136/thx.2010.147884

41. Mansbach JM, Espinola JA, Macias CG, Ruhlen ME, Sullivan AF, Camargo CA Jr. Variability in the diagnostic labeling of nonbacterial lower respiratory tract infections: a multicenter study of children who presented to the emergency department. Pediatrics 2009;123(4):e573-81. http://dx.doi.org/10.1542/peds.2008-1675

42. Jartti T, Korppi M. Rhinovirus-induced bronchiolitis and asthma development. Pediatr Allergy Immunol 2011;22(4):350-5. http://dx.doi.org/10.1111/j.1399-3038. 2011.01170.x

43. Brand PL, Baraldi E, Bisgaard $H$, et al. Definition, assessment and treatment of wheezing disorders in preschool children: an evidence-based approach. Eur Respir J 2008;32(4):1096-110. http://dx.doi.org/10.1183/09031936.00002108

44. American Academy of Pediatrics. Diagnosis and management of bronchiolitis Pediatrics 2006;118(4):1774-93. http://dx.doi.org/10.1542/peds.2006-2223

45. Smyth RL, Openshaw PJ. Bronchiolitis. Lancet 2006;368(9532):312-22. http://dx.doi.org/10.1016/S0140-6736(06)69077-6

46. Hartling L, Fernandes RM, Bialy $L$, et al. Steroids and bronchodilators for acute bronchiolitis in the first two years of life: systematic review and meta-analysis. BMJ 2011;342:d1714

47. Kabir ML, Haq N, Hoque $M$, et al. Evaluation of hospitalized infants and young 
children with bronchiolitis - a multicentre study. Mymensingh Med J: MMJ 2003;12(2):128-33.

48. Hazir T, Qazi S, Nisar YB, et al. Assessment and management of children aged 1-59 months presenting with wheeze, fast breathing, and/or lower chest indrawing: results of a multicentre descriptive study in Pakistan. Arch Dis Child 2004;89(11):1049-54. http://dx.doi.org/10.1136/adc.2003.035741

49. Hazir T, Nisar YB, Qazi SA, et al. Chest radiography in children aged 2-59 months diagnosed with non-severe pneumonia as defined by World Health Organization: descriptive multicentre study in Pakistan. BMJ 2006;333(7569):629. http://dx.doi.org/10.1136/bmj.38915.673322.80

50. Berkley JA, M unywoki $P, N g a m a ~ M$, et al. Viral etiology of severe pneumonia among Kenyan infants and children. JAMA 2010;303(20):2051-7. http://dx.doi.org/10.1001/jama.2010.675

51. Hildenwall H, Nantanda R, Tumwine JK, et al. Care-seeking in the development of severe community acquired pneumonia in Ugandan children. Ann Trop Paediatr 2009;29(4):281-9. http://dx.doi.org/10.1179/027249309X12547917869005

52. Hazir T, Qazi S, Bin NY, et al. Comparison of clinical outcome with oral and inhaled bronchodilators in the management of wheezy children aged 1-59 months in the community: a randomised trial in Pakistan. Int J Tuberc Lung Dis 2004;8(11):130814.

53. Awasthi S, Agarwal G, Singh JV, et al. Effectiveness of 3-day amoxycillin vs. 5-day cotrimoxazole in the treatment of non-severe pneumonia in children aged 2-59 months of age: a multi-centric open labeled trial. J Trop Pediatr 2008;54(6):382-9. http://dx.doi.org/10.1093/tropej/fmn050

54. Addo-Yobo E, Chisaka N, Hassan M, et al. Oral amoxicillin versus injectable penicillin for severe pneumonia in children aged 3 to 59 months: a randomised multicentre equivalency study. Lancet 2004;364(9440):1141-8. http://dx.doi.org/10.1016/S0140-6736(04)17100-6

55. Asher MI, Montefort S, Bjorksten B, et al. Worldwide time trends in the prevalence of symptoms of asthma, allergic rhinoconjunctivitis, and eczema in childhood: ISAAC phases One and Three repeat multicountry cross-sectional surveys. Lancet 2006;368(9537):733-43. http://dx.doi.org/10.1016/50140-6736(06)69283-0

56. Mavale-M anuel $S$, Joaquim $O$, Nunes $E$, et al. Prevalence of asthma-like symptoms by ISAAC video questionnaire in Mozambican schoolchildren. Monaldi Arch Chest Dis 2006;65(4):189-95.

57. Zaman $\mathrm{K}$, Takeuchi $\mathrm{H}$, El Arifeen $\mathrm{S}$, et al. Asthma in rural Bangladeshi children. Indian J Pediatr 2007;74(6):539-43. http://dx.doi.org/10.1007/s12098-007-0104-0

58. Sunyer J, Mendendez C, Ventura PJ, et al. Prenatal risk factors of wheezing at the age of four years in Tanzania. Thorax 2001;56(4):290-5. http://dx.doi.org/10.1136/thorax.56.4.290

59. Benicio MH, Ferreira MU, Cardoso MR, Konno SC, Monteiro CA. Wheezing conditions in early childhood: prevalence and risk factors in the city of Sao Paulo, Brazil. Bull World Health Organ 2004;82(7):516-22.

60. Kallander K, Nsungwa-Sabiiti J, Balyeku A, Pariyo G, Tomson G, Peterson S. Home and community management of acute respiratory infections in children in eight Ugandan districts. Ann Trop Paediatr 2005;25(4):283-91. http://dx.doi.org/10.1179/146532805X72430

61. Hudelson PM. The management of acute respiratory infections in Honduras: a field test of the Focused Ethnographic Study (FES). Med Anthropol 1994;15(4):435-46. http://dx.doi.org/10.1080/01459740.1994.9966104

62. Muhe L. M others' perceptions of signs and symptoms of acute respiratory infections in their children and their assessment of severity in an urban community of Ethiopia. Ann Trop Paediatr 1996;16(2):129-35

63. Redding G], Byrnes CA. Chronic respiratory symptoms and diseases among indigenous children. Pediatr Clin North Am 2009;56(6):1323-42. http://dx.doi.org/10.1016/j.pcl.2009.09.012

64. Levy M. Delay in diagnosing asthma: is the nature of general practice to blame? J R Coll Gen Pract 1986;36(283):52-3.

65. Charlton I, Jones K, Bain J. Delay in diagnosis of childhood asthma and its influence on respiratory consultation rates. Arch Dis Child 1991;66(5):633-5. http://dx.doi.org/10.1136/adc.66.5.633

66. Ostergaard MS, Prahl P. Diagnosis of preschool asthma: parents' comments and typical phrases may ease history-taking. Prim Care Respir J 2007;16(3):194-5. http://dx.doi.org/10.3132/pcrj.2007.00035

67. Ostergaard MS. Childhood asthma: reasons for diagnostic delay and facilitation of early diagnosis: a qualitative study. Prim Care Respir J 2005;14(1):25-30. http://dx.doi.org/10.1016/j.pcrj.2004.06.008

68. Green R, Luyt D. Clinical characteristics of childhood asthmatics in Johannesburg. S Afr Med J 1997;87(7):878-82.

69. Sachdev HP, Mahajan SC, Garg A. Improving antibiotic and bronchodilator prescription in children presenting with difficult breathing: experience from an urban hospital in India. Indian Pediatr 2001;38(8):827-38.

70. Ugandan Health Statistics 2010. 2009.

71. Lodha R, Puranik M, Natchu UC, Kabra SK. Recurrent pneumonia in children: clinical profile and underlying causes. Acta Paediatr 2002;91(11):1170-3. http://dx.doi.org/10.1111/j.1651-2227.2002.tb00123.x

72. Cabezuelo HG, Vidal MS, Abeledo GA, Frontera IP. [Underlying causes of recurrent

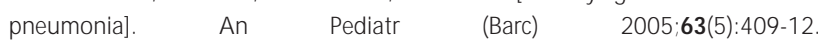
http://dx.doi.org/10.1157/13080405

73. Bustamante-Calvillo ME, Velazquez FR, Cabrera-Munoz L, et al. M olecular detection of respiratory syncytial virus in postmortem lung tissue samples from Mexican children deceased with pneumonia. Pediatr Infect Dis J 2001;20(5):495-501. http://dx.doi.org/10.1097/00006454-200105000-00005

74. Nair H, Nokes DJ, Gessner BD, et al. Global burden of acute lower respiratory infections due to respiratory syncytial virus in young children: a systematic review and meta-analysis. Lancet 2010;375(9725):1545-55.

http://dx.doi.org/10.1016/S0140-6736(10)60206-1

75. Busse WW, Lemanske RF Jr, Gern JE. Role of viral respiratory infections in asthma and asthma exacerbations. Lancet 2010;376(9743):826-34. http://dx.doi.org/10.1016/ S0140-6736(10)61380-3

76. Ostergaard MS. Childhood asthma: parents' perspective: a qualitative interview study. Fam Pract 1998;15(2):153-7. http://dx.doi.org/10.1093/fampra/15.2.153

77. Camargos PA, Lasmar LM. Effects of beclomethasone and factors related to asthma on the growth of prepubertal children. Respir Med 2010;104(7):951-6. http://dx.doi.org/10.1016/j.rmed.2010.02.002

78. Wu X], Huang $Y$, Wang $Y$, Gong $\mathrm{CH}$. [Case-control study of the relationship between children's moderate-severe asthma and development indicators]. Zhonghua yu fang yi xue za zhi [Chinese J Prev Med] 2011;45(3):255-8.

79. Kikafunda JK, Walker AF, Collett D, Tumwine JK. Risk factors for early childhood malnutrition in Uganda. Pediatrics 1998;102(4):E45. http://dx.doi.org/10.1542/ peds.102.4.e45

80. Rice AL, Sacco L, Hyder A, Black RE. Malnutrition as an underlying cause of childhood deaths associated with infectious diseases in developing countries. Bull World Health Organ 2000;78(10):1207-21.

81. Lima MC, Motta ME, Santos EC, Pontes da Silva GA. Determinants of impaired growth among hospitalized children: a case-control study. Sao Paulo Med J 2004;122(3):117-23. http://dx.doi.org/10.1590/S1516-31802004000300008

82. McKean M, Ducharme F. Inhaled steroids for episodic viral wheeze of childhood. Cochrane Database Syst Rev 2000;(2):CD001107.

83. Volovitz B, Bentur L, Finkelstein $Y$, et al. Effectiveness and safety of inhaled corticosteroids in controlling acute asthma attacks in children who were treated in the emergency department: a controlled comparative study with oral prednisolone. J Allergy Clin Immunol 1998;102(4 Pt 1):605-9. http://dx.doi.org/10.1016/S0091-6749(98)70276-3

84. Volovitz B, Soferman R, Blau H, Nussinovitch M, Varsano I. Rapid induction of clinical response with a short-term high-dose starting schedule of budesonide nebulizing suspension in young children with recurrent wheezing episodes. J Allergy Clin Immunol 1998;101(4 Pt 1):464-9. http://dx.doi.org/10.1016/S0091-6749(98)70405-1

85. Malmstrom K, Kaila M, Kajosaari M, Syvanen P, Juntunen-Backman K. Fatal asthma in Finnish children and adolescents 1976-1998: validity of death certificates and a clinical description. Pediatr Pulmonol 2007;42(3):210-15. http://dx.doi.org/ 10.1002/ppul.20552

86. Ait-Khaled N, Enarson DA, Bissell K, Billo NE. Access to inhaled corticosteroids is key to improving quality of care for asthma in developing countries. Allergy 2007;62(3):230-6. http://dx.doi.org/10.1111/j.1398-9995.2007.01326.x

87. Haines A, Cassels A. Can the millennium development goals be attained? BMJ 2004;329(7462):394-7. http://dx.doi.org/10.1136/bmj.329.7462.394

88. Bryce J, Daelmans B, Dwivedi A, et al. Countdown to 2015 for maternal, newborn, and child survival: the 2008 report on tracking coverage of interventions. Lancet 2008;371(9620):1247-58. http://dx.doi.org/10.1016/S0140-6736(08)60559-0 